American Journal of Animal and Veterinary Sciences 5 (1): 27-32, 2010

ISSN 1557-4555

(C) 2010 Science Publications

\title{
Effect of Dietary Protein and Lysine on Performance and Carcass Yield of Turkeys
}

\author{
F. Peñaranda-Ali, R. Santos-Ricalde, L. Sarmiento-Franco, J. Segura-Correa and M. Gutierrez-Triay \\ Campus of Biological and Farming Sciences, University of Yucatan, \\ Km 15.5 Carr, Merida-Xmatkuil, Ap. Postal 4-116 Itzimna, Merida, Yucatan, Mexico
}

\begin{abstract}
Problem statement: There is a concern related to loss of nitrogen to the environment from animal manure and the high cost of the protein supplement. Thus, the current study was undertaken to determine the effect of reduction of $\mathrm{CP}$ and increased of lysine on growth and carcass yield in turkeys. Approach: A factorial experiment was carried out with commercial turkeys to evaluate the effect of two dietary levels of CP (90 and 100\% of the NRC recommendations) and three dietary lysine levels (90, 110 and $130 \%$ of the NRC recommendations) on performance and carcass yield of male turkeys evaluated from 8-16 week of age. Results: The $\mathrm{CP} \times$ lysine interaction was significant $(\mathrm{p}<0.05)$ for daily gain and Food Conversion Ratio (FCR). 100\% CP level increased daily gain (0.13, 0.15 and $\left.0.15 \mathrm{~kg} \mathrm{day}^{-1}\right)$ and improved FCR $(3.43,3.12$ and 3.01) as dietary levels of lysine in the diet increased $(\mathrm{p}<0.05)$, but the opposite was true for the birds fed $90 \% \mathrm{CP}$. The CP $\times$ lysine interaction $(\mathrm{p}<0.05)$ observed at 16 week of age showed that carcass weigh, breast weight, leg weight and thigh weight increased as the lysine level increased in the diet with $100 \% \mathrm{CP}$ and the contrary occurred in the $90 \%$ $\mathrm{CP}$ treatment. Conclusion: The results of this experiment suggest a positive relationship between amino acids and CP; however, the increment of amino acids in the diets with low CP should be made keeping a proportional relationship among the dietary amino acids.
\end{abstract}

Key words: Lysine, protein, turkey performance, carcass yield

\section{INTRODUCTION}

Protein and amino acids are the nutrients of most economic value in the diet of turkeys and should be provided in appropriate amounts to minimize feeding costs. More recently, concerns about environmental pollution has encouraged nutritionist to decrease Crude Protein (CP) levels in the diet of turkeys whilst sustaining performance. Diverse studies postulate that it is possible to reduce the level of $\mathrm{CP}$ in the diet without any disturbance on performance, whereas an appropriate level of the essential Amino Acids (AA) is provided (Kidd et al., 1997; Lemme et al., 2004; Waldroup et al., 1997; Waibel et al., 2000a). Also, it has been proposed an ideal protein ratio for turkeys (Firman and Boling, 1998; Boling and Firman, 1997). The ideal protein indicates the exact balance of AA's needed for growth and maintenance without excesses or deficiencies. This supposed reduces of feed costs and excess levels of nitrogen losses into the manure. Ideal protein has been well-defined in broilers (Baker, 2003), but little data exists on an ideal protein for turkeys. Lysine has been chosen as the reference AA because it is the second limiting in poultry rations, there is a relatively large amount of data available and lysine is primarily used for protein accretion (Firman, 2004). The information available showed that lysine level recommended by National Research Council (1994) for turkeys do not sustain satisfactorily growth rate (Lemme et al., 2002). The estimations of lysine requirements in turkeys could vary due to inherent factors on growth rate and food consumption, as well as to environmental factors (Boling and Firman, 1998; Waldroup et al., 1997). Therefore, the objective of this study was to evaluate the effect of dietary lysine and protein levels on the productive performance and carcass yield in modern genetic strains of commercial turkeys.

\section{MATERIALS AND METHODS}

A two-period experiment was carried out at the Faculty of Veterinary Medicine and Animal Science (University of Yucatan). The average maximum temperatures during the first and second periods were $27.6 \pm 3.70$ and $26.4 \pm 3.00^{\circ} \mathrm{C}$ and the minimum $21.1 \pm 3.73$ and $20.3 \pm 2.52^{\circ} \mathrm{C}$, respectively. Eight week old male turkeys (Nicholas-700) with average BW of $3.37 \pm 0.27$ and $4.20 \pm 0.36 \mathrm{~kg}$ were used in the first and second period. Thirty six turkeys were used in each period.

Corresponding Author: Ronald Santos-Ricalde, Campus of Biological and Farming Sciences, University of Yucatan, Km. 15.5 Carretera Mérida-Xmatkuil, Apdo, Postal 4-116 Itzimna. Merida, Yucatan, Mexico Tel: +52 (999) 9423200 Fax: +52 (999) 9423205 
American J. Animal \& Vet. Sci., 5 (1): 27-32, 2010

Six diets consisting of combinations of two CP levels (90 and 100\% of the National Research Council (1994) recommendations) and three lysine levels (90, 110 and $130 \%$ of the National Research Council (1994) recommendations) were used (Table 1). Lysine levels were reached by the addition of L-lysine HCL and formulated to meet the requirement of the other $\mathrm{AA}$ according to the National Research Council (1994). The calculated nutrient values of the diets are shown in Table 2.

Table 1: Diet formulation for male turkeys diets from 8-16 weeks of age, with different levels of Crude Protein (CP) and Lysine (LYS)

\begin{tabular}{|c|c|c|c|c|c|c|}
\hline \multirow[b]{2}{*}{ Ingredient $(\%)$} & \multicolumn{3}{|l|}{$90 \% \mathrm{CP}$} & \multicolumn{3}{|l|}{$100 \% \mathrm{CP}$} \\
\hline & $90 \%$ LYS & $110 \%$ LYS & $130 \%$ LYS & $90 \%$ LYS & $110 \%$ LYS & $130 \%$ LYS \\
\hline Sorghum & 53.80 & 54.15 & 54.80 & 51.03 & 50.68 & 50.35 \\
\hline Soybean meal & 23.99 & 23.32 & 22.32 & 28.82 & 28.84 & 28.84 \\
\hline Canola meal & 9.99 & 10.00 & 9.99 & 10.00 & 10.00 & 10.00 \\
\hline Soybean oil & 6.15 & 6.15 & 6.15 & 4.49 & 4.49 & 4.49 \\
\hline Wheat bran & 2.00 & 2.00 & 2.00 & 2.00 & 2.00 & 2.00 \\
\hline Dicalcium phosphate & 1.83 & 1.80 & 1.80 & 1.70 & 1.70 & 1.70 \\
\hline $\mathrm{CaCO} 38 \%$ & 0.83 & 0.84 & 0.84 & 0.84 & 0.84 & 0.84 \\
\hline Sodium chloride & 0.30 & 0.30 & 0.30 & 0.30 & 0.30 & 0.30 \\
\hline Lysine HCL & 0.27 & 0.61 & 0.97 & 0.10 & 0.43 & 0.77 \\
\hline Flavomicine $4 \%$ & 0.25 & 0.25 & 0.25 & 0.25 & 0.25 & 0.25 \\
\hline Methionine $99 \%$ & 0.15 & 0.15 & 0.15 & 0.09 & 0.09 & 0.09 \\
\hline Vitamin premix ${ }^{a}$ & 0.10 & 0.10 & 0.10 & 0.10 & 0.10 & 0.10 \\
\hline L-threonine ADM & 0.07 & 0.07 & 0.07 & 0.00 & 0.00 & 0.00 \\
\hline Mycosorb $^{\mathrm{b}}$ & 0.05 & 0.05 & 0.05 & 0.05 & 0.05 & 0.05 \\
\hline Lasalocid sodium & 0.05 & 0.05 & 0.05 & 0.05 & 0.05 & 0.05 \\
\hline Mineral premix ${ }^{\mathrm{c}}$ & 0.05 & 0.05 & 0.05 & 0.05 & 0.05 & 0.05 \\
\hline Choline chloride $^{\mathrm{d}}$ & 0.05 & 0.05 & 0.05 & 0.05 & 0.05 & 0.05 \\
\hline Funginat 42 & 0.05 & 0.05 & 0.05 & 0.05 & 0.05 & 0.05 \\
\hline Oxidox beta & 0.01 & 0.01 & 0.01 & 0.01 & 0.01 & 0.01 \\
\hline Manganese & 0.01 & 0.01 & 0.01 & 0.01 & 0.01 & 0.01 \\
\hline
\end{tabular}

a: Content $\mathrm{kg}^{-1}$ : vitamin A, $8000 \mathrm{UI}$; vitamin D, $2500 \mathrm{UI}$; vitamin E, $8 \mathrm{UI}$; vitamin $\mathrm{K}, 2 \mathrm{mg}$; vitamin B12, 0.002 mg; riboflavin, 5.5 mg; pantothenate of calcium, $13 \mathrm{mg}$; niacine, $36 \mathrm{mg}$; choline, $500 \mathrm{mg}$; folic acid, $0.5 \mathrm{mg}$; thiamine, $1 \mathrm{mg}$; pyridoxine, $2.2 \mathrm{mg}$; biotin, $0.05 \mathrm{mg}$; ${ }^{\circ}$ : Micotoxin sequestering; ${ }^{\mathrm{c}}$ : Content $\mathrm{kg}^{-1}$ of diet: Manganese, $65 \mathrm{mg}$; iodine, $1 \mathrm{mg}$; iron, $55 \mathrm{mg}$, copper, $6 \mathrm{mg}$; zinc, $55 \mathrm{mg}$; selenium, $0.3 \mathrm{mg}$; $: 700 \mathrm{~g} \mathrm{~kg}{ }^{-1}$ of choline chloride

Table 2: Nutrient composition and AA: Lisine ratio of the experimental diets with different levels of Crude Protein (CP) and Lysine (LYS) for male turkeys from $8-16$ weeks of age

\begin{tabular}{|c|c|c|c|c|c|c|}
\hline \multirow[b]{2}{*}{ Nutrient composition (\%) } & \multicolumn{3}{|l|}{$90 \% \mathrm{CP}$} & \multicolumn{3}{|l|}{$100 \% \mathrm{CP}$} \\
\hline & $90 \%$ LYS & $110 \%$ LYS & $130 \%$ LYS & $90 \%$ LYS & $130 \%$ LYS & $110 \%$ LYS \\
\hline ME, Mcal kg ${ }^{-1}$ & 3.00 & 3.00 & 3.00 & 3.00 & 3.00 & 3.00 \\
\hline Crude protein & 19.80 & 19.90 & 19.80 & 21.50 & 21.80 & 22.10 \\
\hline Crude fiber & 3.20 & 3.20 & 3.20 & 3.20 & 3.20 & 3.20 \\
\hline Non-phytate phosphorus & 0.40 & 0.40 & 0.40 & 0.40 & 0.40 & 0.40 \\
\hline Calcium & 0.90 & 0.90 & 0.90 & 0.90 & 0.90 & 0.90 \\
\hline \multicolumn{7}{|l|}{ Amino acids (\%) } \\
\hline Lysine & 1.20 & 1.40 & 1.70 & 1.20 & 1.40 & 1.70 \\
\hline Arginine & 1.20 & 1.20 & 1.10 & 1.30 & 1.30 & 1.30 \\
\hline Met + Cystine & 0.80 & 0.80 & 0.80 & 0.80 & 0.80 & 0.80 \\
\hline Threonine & 0.80 & 0.80 & 0.80 & 0.80 & 0.80 & 0.80 \\
\hline Isoleucine & 0.80 & 0.80 & 0.80 & 0.90 & 0.90 & 0.90 \\
\hline Phenylalanine & 0.90 & 0.90 & 0.90 & 1.00 & 1.00 & 1.00 \\
\hline Valine & 0.90 & 0.90 & 0.90 & 1.00 & 1.00 & 1.00 \\
\hline Tryptophan & 0.30 & 0.30 & 0.30 & 0.30 & 0.30 & 0.30 \\
\hline Histidine & 0.50 & 0.50 & 0.50 & 0.60 & 0.60 & 0.60 \\
\hline Leucine & 1.70 & 1.70 & 1.70 & 1.80 & 1.80 & 1.80 \\
\hline Glys + serine & 1.80 & 1.70 & 1.70 & 1.90 & 1.90 & 1.90 \\
\hline \multicolumn{7}{|l|}{ AA: Lysine ratio } \\
\hline Arginine: Lysine & 1.00 & 0.85 & 0.65 & 1.08 & 0.93 & 0.76 \\
\hline Met + Cystine: Lysine & 0.67 & 0.57 & 0.47 & 0.67 & 0.57 & 0.47 \\
\hline Threonine: Lysine & 0.67 & 0.57 & 0.47 & 0.67 & 0.57 & 0.47 \\
\hline Tryptophan: Lysine & 0.25 & 0.21 & 0.18 & 0.25 & 0.21 & 0.18 \\
\hline Valine: Lysine & 0.75 & 0.64 & 0.53 & 0.83 & 0.71 & 0.59 \\
\hline Isoleucine: Lysine & 0.67 & 0.57 & 0.47 & 0.75 & 0.64 & 0.53 \\
\hline Leucine: Lysine & 1.42 & 1.21 & 1.00 & 1.50 & 1.29 & 1.06 \\
\hline
\end{tabular}


Experimental diets were provided ad libitum, in pellet form. One week before the beginning of the experiment turkeys were kept in floor pens. During adaptation time, birds consumed the same food used in their former farm $(22 \% \mathrm{CP}, 2.8 \% \mathrm{EE}, 12 \%$ humidity, $4.5 \% \mathrm{CF}$ and $10 \%$ ash). The turkeys were distributed at random in 18 floor pens ( 2 birds per pen) and assigned to one of the six experimental diets. Each pen had $1 \mathrm{~m}^{2}$ concrete floor, covered with wood shavings as bed and equipped with a hanging feeder and an automatic drinker. During the study the birds underwent a regime of natural light. Turkeys were fed the diets from 816 week of age and at 16 week of age they were fasted for $12 \mathrm{~h}$, weighted and food consumption calculated. A bird from each pen was randomly selected, killed and carcass measurements recorded.

Slaughter consisted on stunning the turkeys with an electric discharge and then cutting off the jugular vein for bleeding. Later on, they were scalded at $60^{\circ} \mathrm{C}$ for $1 \mathrm{~min}$ and plucked. Finally birds were eviscerated manually, eliminating the neck, head, paws and guts. The hot carcass, the breast from the right half of each carcass (without skin and bones), the thigh, the leg and the wing (with the skin and bone) were weighed. The weights of half of the carcass components were multiplied by 2 to obtain the total yield of the carcass components.

Average weight/bird/pen was calculated. Daily food consumption was considered, as the average food consumption/bird/pen. The average feed conversion ratio/bird/pen was calculated dividing the average daily food consumption/bird/pen by the average body weight/bird/pen. Carcass yield was calculated as a proportion of body weight. Breast, leg, wing and thigh yields were calculated as proportions of the carcass weight.

Data of each period and both combined were analyzed as a factorial experiment. The factors considered in the analysis of each period were protein levels (90 and $100 \%$ of NRC recommendations), lysine levels (90, 110 and $130 \%$ of NRC recommendations) and $\mathrm{CP} \times$ lysine interaction. The statistical model for the combined data also included the effect of period. Polynomial orthogonal analyses were further carried out to evaluate the linear and quadratic effects of the lysine levels for each level of CP. Pen was considered the experimental unit and there were 6 replicates per treatment. The ANOVA of the data was carried out using the STATGRAPHICS statistical program (Statgraphics Plus 5.1 for Windows, 2001).

\section{RESULTS}

Nutrient compositions of experimental diets are shown in Table 2. The relation of AA: Lysine of diets were as expected reduces conforming Lysine increasing in both low and high protein diets. The results of Daily Weight Gain (DWG), Daily Feed Consumption (DFC) and Feed Conversion Ratio (FCR) are presented in Table 3. There were not significant effect of $\mathrm{CP}$ and lysine level in the diets on growth performance $(p>0.05)$, however, $\mathrm{CP} \times$ lysine interaction $(\mathrm{p}<0.05)$ was observed for DWG. The DWG of birds fed diets with $90 \%$ of CP, tend to decrease as lysine level increased from 90-110 and $130 \% \quad\left(0.151,0.132\right.$ and $0.135 \mathrm{~kg} \mathrm{day}^{-1}$, respectively). On the other hand, the DWG of birds fed diets with $100 \%$ of CP increased as the lysine level increased from 90 to 110 and 130 (0.132, 0.149 and $0.147 \mathrm{~kg} \mathrm{day}^{-1}$, respectively). Similarly, a significant interaction $\mathrm{CP} \times$ lysine was observed $(\mathrm{p}<0.05)$ for FCR. In birds consuming the diets with $90 \%$ of $\mathrm{CP}$ the FCR increased quadratically as the dietary lysine increased (2.89, 3.28 and 3.08). However, FCR of birds fed diets with $100 \%$ CP showed a linear decreased $(\mathrm{p}<0.05)$ as the lysine level increased (3.43, 3.12 and 3.01).

Table 4 shows the carcass weight and relative organ weights as affected by dietary concentration of $\mathrm{CP}$ and Lysine. The thigh yield was significantly $(\mathrm{p}<0.05)$ reduced with decreasing $\mathrm{CP}$ and lysine in the diet. Nevertheless, a significant interaction $(p<0.05)$ was observed in this study between the levels of CP and lysine for the carcass, breast, leg and thigh weights.

Table 3: Mean performance of male turkeys fed with different dietary lysine (LYS) and crude protein (CP) levels

\begin{tabular}{lclll}
\hline Factor & & $\begin{array}{l}\text { Daily } \\
\text { gain } \\
(\mathrm{Kg})\end{array}$ & $\begin{array}{l}\text { Food } \\
\text { consumption } \\
(\mathrm{Kg})\end{array}$ & $\begin{array}{l}\text { Feed } \\
\text { conversion }\end{array}$ \\
\hline $\mathrm{CP}(\%)$ & LYS $(\%)$ & 0.1510 & 0.4320 & 2.9000 \\
\hline 90 & 90 & 0.1320 & 0.4310 & 3.3000 \\
90 & 110 & 0.1350 & 0.4160 & 3.1000 \\
90 & 130 & 0.1320 & 0.4480 & 3.4000 \\
100 & 90 & 0.1490 & 0.4630 & 3.1000 \\
100 & 110 & 0.1470 & 0.4420 & 3.0000 \\
100 & 130 & 0.0023 & 0.0069 & 0.0400 \\
SE & & 0.1410 & 0.4390 & 3.1000 \\
Mean & & & & \\
p-values & & 0.8861 & 0.0089 & 0.0016 \\
B & & 0.4757 & 0.0845 & 0.2580 \\
CP & 0.9845 & 0.5838 & 0.3316 \\
LYS & & 0.0076 & 0.8963 & 0.0052 \\
CP $\times$ LYS & & & \\
Contrast for lysine level & & & \\
$90 \%$ CP & & & & \\
Linear & & 0.0596 & 0.5113 & 0.2273 \\
Quadratic & & 0.1228 & 0.7579 & 0.0335 \\
100\% CP & & & \\
Linear & & 0.0767 & 0.7921 & 0.0090 \\
Quadratic & & 0.1803 & 0.4074 & 0.4451 \\
\hline LYS: Lys $;$ CP: Crude Pron
\end{tabular}

LYS: Lysine; CP: Crude Protein; B: Block; P: Probability value; SE: Standard Error 
American J. Animal \& Vet. Sci., 5 (1): 27-32, 2010

Table 4: Carcass yield in turkeys fed on different dietary Lysine (LYS) and Crude Protein (CP) levels at 16 week-old

\begin{tabular}{|c|c|c|c|c|c|c|c|c|c|c|c|c|}
\hline \multicolumn{2}{|l|}{ Factor } & \multirow{2}{*}{$\begin{array}{l}\text { Live } \\
\text { weight } \\
(\mathrm{kg})\end{array}$} & \multirow{2}{*}{$\begin{array}{l}\text { Carcass } \\
\text { weight } \\
(\mathrm{kg})\end{array}$} & \multirow{2}{*}{$\begin{array}{l}\text { Yield } \\
(\%)\end{array}$} & \multicolumn{2}{|l|}{ Breast } & \multicolumn{2}{|l|}{ Leg } & \multicolumn{2}{|l|}{ Thigh } & \multicolumn{2}{|l|}{ Wing } \\
\hline $\mathrm{CP}$ & LYS & & & & $(\mathrm{kg})$ & $(\%)$ & $(\mathrm{kg})$ & $(\%)$ & $(\mathrm{kg})$ & $(\%)$ & $(\mathrm{kg})$ & $(\%)$ \\
\hline$\overline{90}$ & 90 & 12.6000 & 8.9000 & 71.2000 & 2.6000 & 28.8000 & 1.3000 & 14.7000 & 1.5000 & 17.0000 & 1.1000 & 12.5000 \\
\hline 90 & 110 & 11.5000 & 5000 & 73.8000 & 5000 & 29.0000 & 1.3000 & 4.7000 & .4000 & 16.0000 & 1.0000 & 12.1000 \\
\hline 90 & 130 & 11.1000 & 8.0000 & 71.8000 & 1000 & 26.7000 & 1.2000 & 14.8000 & 1.3000 & 16.3000 & 1.0000 & 13.0000 \\
\hline 100 & 90 & 10.9000 & 8.1000 & 73.7000 & 2.3000 & 28.7000 & 1.1000 & 14.0000 & 1.3000 & 15.9000 & 1.0000 & 12.1000 \\
\hline 100 & 110 & 12.1000 & 8.8000 & 72.8000 & 2.6000 & 29.8000 & 1.3000 & 14.3000 & 1.4000 & 16.1000 & 1.0000 & 11.8000 \\
\hline 100 & 130 & 11.9000 & 8.7000 & 73.7000 & 2.6000 & 30.1000 & 1.3000 & 14.4000 & 1.3000 & 15.1000 & 1.0000 & 11.9000 \\
\hline SE & & 0.1400 & 0.1100 & 0.3700 & 0.0500 & 0.3400 & 0.0200 & & 0.0200 & 100 & 0.0200 & 0.1600 \\
\hline $\mathrm{N}$ & & 36.0000 & 36.0000 & 36.0000 & 36.0000 & 36.0000 & 36.0000 & 36.0000 & 36.0000 & 36.0000 & 36.0000 & 36.0000 \\
\hline \multicolumn{4}{|l|}{ p-values } & 72.8000 & & 28 & & & 00 & 000 & 000 & 12.2000 \\
\hline B & & 0.0657 & s & 580 & & & 99 & & & & 31 & 0.1716 \\
\hline $\mathrm{CP}$ & & 0.6080 & .8314 & 0.1296 & & & 0.3846 & & & & 0.2769 & 0.0703 \\
\hline LYS & & 0.6192 & 0.5715 & 0.6714 & 0.3796 & 0.4834 & 0.7404 & 885 & 0.1020 & 0.0315 & 0.9832 & 0.4410 \\
\hline $\mathrm{CP} \times \mathrm{LYS}$ & & 0.0031 & 0.0149 & 0.1381 & 0.0089 & 0.1021 & 0.0343 & 0.9241 & 0.0058 & 0.0460 & 0.2339 & 0.5675 \\
\hline \multicolumn{13}{|c|}{$\begin{array}{l}\text { Contrast for lysine level } \\
90 \% \text { CP }\end{array}$} \\
\hline Linear & & 0.0058 & & & & & & & & & & 216 \\
\hline Quadratic & & 0.4878 & 0.8838 & 0.0510 & 5 & 56 & 0.9564 & 0.9245 & 0.4524 & 0.0830 & 5007 & 0.2239 \\
\hline Linear & & & 0 . & 48 & & & & & & & & 0.7813 \\
\hline Quadratic & & 0.1339 & 0.2608 & 0.4096 & 0.3056 & 0.6791 & 0.3158 & 0.8634 & 0.0437 & 0.0667 & 0.6129 & 0.6614 \\
\hline
\end{tabular}

LYS: Lysine; CP: Crude Protein; B: Block; P: Probability value; SE: Standard Error

The carcass, breast, leg and thigh weights reduces as lysine increases in $90 \% \mathrm{CP}$ diets and contrary increases as lysine increases in $100 \% \mathrm{CP}$ diets.

\section{DISCUSSION}

The significant positive linear relationship between the increase in dietary lysine and the daily gain and food consumption found in the current study in turkeys fed $100 \%$ CP diets, is in good agreement with the linear response reported by Veldkamp et al. (2000). Inversely, the negative response observed in $90 \% \mathrm{CP}$ diets conforming increased lysine can be related to the reduction of lysine: Other AA ratio, particularly with arginine (Table 2) that is an antagonistic AA of the lysine (Brake et al., 1998) and valine, leucine and isoleucine that are important for optimum growth (Lemme et al., 2004). These results are also associated to the hypothesis suggesting that an adequate balance among the dietary AA it is necessary in order to meet the requirements of the birds (Applegate et al., 2008; Baker et al., 2003; Boling and Firman, 1998; Firman and Boling, 1998). According to Lemme et al. (2002) the dietary AA imbalances result in a reduction of $\mathrm{BWG}$, increases in the FCR and reduction of carcass yield. The results obtained in this experiment indicate that diets containing $90 \% \mathrm{CP}$ and $90 \%$ lysine supported the growing performance of the turkeys, while, in diets having $100 \% \mathrm{CP}$, the $90 \%$ of lysine was not sufficient. The lysine content in diets with $100 \%$ of $\mathrm{CP}$ had to be higher to sustain the growing performance of the turkeys. The increased of CP in the diets, increased also content of other AA such as arginine and valine, so, the increased of lysine to keep an appropriate relationship among AA could be required (Table 2). The imbalance in the essential amino acids could be caused by the increasing level of the $\mathrm{CP}$ or the $\mathrm{AA}$, without consideration of the relation between both (Corzo et al., 2002).

The carcass, breast, leg and thigh weights reduction as lysine increases in $90 \% \mathrm{CP}$ are also associated with the imbalance of amino acids observed in the diet containing $90 \% \mathrm{CP}$. In Table 2 it is demonstrated that as the lysine level in the diet increased, they became more limiting to other amino acids, e.g., arginine, valine, isoleucine and leucine, that are important for optimum growth (Lemme et al., 2004). On the other hand, in diets with $100 \% \mathrm{CP}$ the dietary levels of those AA were higher and they probably kept better relationship with lysine. These results agreed with that reported by Waldroup et al. (2003) who confirmed that as an amino acid becomes more limiting in the diet the protein content in the carcass decreases. Similarly to the results obtained in the current research, Corzo et al. (2002) found that increasing the lysine level in the diet of finishing male chickens (42-56 day of age) decreased the breast yield and incremented the FCR. These authors explained their results as a function of the imbalance in the essential amino acids caused by the increasing level of the dietary lysine. In this respect, several reports mention the importance of considering other essential amino acids besides the lysine in order 
to improve the breast yield when diets with low $\mathrm{CP}$ content are used (Kidd and Kerr, 1996; Kidd and Kerr, 1998; Veldkamp et al., 2003; Veldkamp et al., 2005; Waibel et al., 2000b). Waibel et al. (2000b) mentioned that the supplementation with threonine, isoleucine, valine, arginine and tryptophan improved the breast yield in turkeys. Kidd et al. (1997) reported that the proportional increment of the sulfur amino acids, lysine, threonine and triptophan in low protein diets (92\% of the NRC recommendations) improved the yield of the breast in male turkeys. In contrast, Applegate et al. (2008) demonstrates that diets containing AA formulations above NRC recommendations do not provide any additional performance or breast yield benefits in turkeys. Other reports, found that improving the relationship among AA (e.g., arginine: Lysine) increased both the breast yield and the DWG and decreased the FCR in turkeys (Firman and Boling, 1998).

\section{CONCLUSION}

The results obtained suggested that a $\mathrm{CP}$ reduction of $10 \%$ in turkey diets could be possible, as long as a corresponding relationship exist among the amino acids. Increases of lysine in low protein diets could allow an unbalance among the essential aminoacids, so a reduction in productive performance can be observed in the turkeys. On the other hand, increase lysine in diets with protein according requirements allowed an increase in the productive performance until a point where no longer there was improvement in the productive performance of the turkeys. These assertions emphasize to lysine like an amino acid from which an ideal protein model for turkeys can be designed. Also, more information on the ideal relationship among amino acids in diets for turkeys is necessary due to the continuous genetic improvement in that specie.

\section{ACKNOWLEDGEMENT}

The researchers express many thanks to Pavos Paraiso and Alimentos Balanceados Lorgam for funding and technical support.

\section{REFERENCES}

Applegate, T., W. Powers, R. Angel and D. Hoehler, 2008. Effect of amino acid formulation and amino acid supplementation on performance and nitrogen excretion in Turkey toms. Poult. Sci., 87: 524-520. DOI: $10.3382 /$ ps.2007-00375
Baker, D.H., 2003. Ideal Amino Acid Patterns for Broiler Chicks. In: Amino Acids, Animal Nutrition, D’Mello, J.P.F. (Ed.), 2nd Edn., CAB International, Wallingford, Oxon, UK, ISBN 085199654X, pp: 223-235.

Baker, K., J.D. Firman, E. Blair, J. Brown and D. Moore, 2003. Digestible lysine requirements of male Turkeys during the 12 to 18 week period. Int. J. Poult. $\quad$ Sci., 2: 229-233. http://www.pjbs.org/ijps/fin93.pdf

Boling, S.D. and J.D. Firman, 1997. Digestible sulfur amino acid requirement of starting Turkeys. Poult. Sci., $\quad 76:$ 873-877. http://ps.fass.org/cgi/reprint/76/6/873

Boling, S.D. and J.D. Firman, 1998. Digestible lysine requirement of female Turkeys during the starter period. Poult. Sci., 77: 547-551. http://ps.fass.org/cgi/reprint/77/4/547

Brake, J., D. Balnave and J.J. Dibner, 1998. Optimun dietary arginine: Lysine ratio for broiler chickens is altered during heat stress in association with changes in intestinal uptake an dietary sodium chloride. Brit. Poult. Sci., 39: 639-647. http://dx.doi.org/10.1080/00071669888511

Corzo, A., E.T. Moran Jr. and D. Hoehler, 2002. Lysine need of heavy broiler males applying the ideal protein concept. Poult. Sci., 81: 1863-1868. http://ps.fass.org/cgi/reprint/81/12/1863

Firman, J., 2004. Digestible lysine requirements of male Turkeys in their 1st six weeks. Int. J. Poult. Sci., 3: 373-377. http://www.pjbs.org/ijps/fin217.pdf

Firman, J.D. and S.D. Boling, 1998. Ideal protein in Turkeys. Poult. Sci., 77: 105-110. http://ps.fass.org/cgi/reprint/77/1/105

Kidd, M.T. and B.J. Kerr, 1996. L-threonine for poultry. Rev. J. Applied Poult. Res., 5: 358-367. http://japr.fass.org/cgi/reprint/5/4/358

Kidd, M.T. and B.J. Kerr, 1998. Dietary arginine and lysine ratios in large white toms. 2 Lack of interaction between arginine: Lysine ratios and electrolyte balance. Poult. Sci., 77: 864-869. http://ps.fass.org/cgi/reprint/77/6/864

Kidd, M.T., B.J. Kerr, J.A. England and P.W. Waldroup, 1997. Performance and carcass composition of large white toms as affected by dietary crude protein and threonine supplements. Poult. Sci., 76: 1392-1397. http://ps.fass.org/cgi/reprint/76/10/1392

Lemme, A., E. Strobel, D. Hoehler, W. Matzke, M. Pack and H. Jeroch, 2002. Impact of graded levels of dietary lysine on performance in Turkey toms 5 to 8 and 13 to16 weeks of age. Arch. Geflügelk., 66: 102-107. http://www.ulmer.de/Artikel.dll/s-102107_NzkzOQ.PDF?UID=49A9C4F78B3203A1E5 7837DA4E9FB4B5C18C6C963165D1 
Lemme, A., U. Frackenpohl, A. Petri and H. Meyer, 2004. Effects of reduced dietary protein concentrations with amino acid supplementation on performance and carcass quality in Turkey toms 14-140 days of age. Int. J. Poult. Sci., 3: 391-399. http://www.pjbs.org/ijps/fin220.pdf

National Research Council, (NCR), 1994. Nutrient requirements of Poultry. 9th Rev. Edn., National Academic Press, Washington DC., ISBN: 0309048923.

Statgraphics Plus 5.1 for Windows, 2001. Statistical graphics system by statistical graphics corporation. http://www.statgraphics.com/statgraphics_plus.htm

Veldkamp, T., P.R. Ferket, R.P. Kawakkel, C. Nixey and J.P.T.M. Noordhuizen, 2000. Interaction between ambient temperature and supplementation of synthetic amino acids on performance and carcass parameters in commercial male Turkeys. Poult. $\quad$ Sci., $\quad 79$ : 1472-1477. http://ps.fass.org/cgi/reprint/79/10/1472

Veldkamp, T., R. Kwakkel, P. Ferket, J. Kogut and M. Verstegen, 2003. Growth responses to dietary lysine at high and low ambient temperature in male Turkeys. Poult. Sci., 82: 1733-1746. http://ps.fass.org/cgi/reprint/79/10/1472

Veldkamp, T., R.P. Kwakkel, P.R. Ferket and M.W.A. Verstegen, 2005. Growth responses to dietary energy and lysine at high and low ambient temperature in male Turkeys. Poult. Sci., 84: 273-282. http://ps.fass.org/cgi/reprint/84/2/273
Waibel, P.E., C.W. Carlson, J.A. Brannon and S.L. Noll, 2000a. Identification of limiting amino acids in methionine and lysine supplemented low protein diets for Turkeys. Poult. Sci., 79: 1299-1305. http://ps.fass.org/cgi/reprint/84/2/273

Waibel, P.E., C.W. Carlson, J.A. Brannon and S.L. Noll, 2000b. Limiting amino acids after methionine and lysine with growing Turkeys fed low protein diets. Poult. Sci., 79: 1290-1298. http://ps.fass.org/cgi/reprint/84/2/273

Waldroup, P.W., C.A. Fritts, J.H. Kersey, E.A. Saleh, B.J. Kerr and M.T. Kidd, 2003. Evaluation of crude protein needs for large white male Turkeys from 16 to 20 weeks of age. Int. J. Poult. Sci., 2: 15-18. http://www.pjbs.org/ijps/fin49.pdf

Waldroup, P.W., M.H. Adams and A.L. Waldroup, 1997. Evaluation of national research council amino acid recommendations for large white Turkeys. Poult. Sci., 76: 711-720. http://ps.fass.org/cgi/reprint/76/5/711 